STUDIA HISTORICA GEDANENSIA

TOM X (2019)

\author{
Magdalena Nowak \\ (Wydział Historyczny, Uniwersytet Gdański)
}

\title{
Gente Rutheni, natione Poloni in Polish and Ukrainian scholarly encyclopaedias and biographical dictionaries
}

The phenomenon of national identity, its definition and origins have been the topic of scholarly discussions for many years. There were many theories explaining how nationalities appeared and how they actually work. In Poland they have been listed and analysed by such historians as Łukasz Adamski ${ }^{1}$, Adam Świątek ${ }^{2}$ or Marta Studenna-Skrukwa ${ }^{3}$. Taking into consideration results of their research, I would like to refer to the theory of modern nation. Such authors as Ernest Gellner, Miroslav Hroch, Benedict Anderson, Józef Chlebowczyk and Krzysztof Pomian wrote about the role of modernization in modern nation forming in Central and Eastern Europe 4 . Especially E. Gellner, M. Hroch and B. Anderson stated that nations as a modern "imagined communities" appeared in the second half of the $19^{\text {th }}$ century and at the beginning of the $20^{\text {th }}$ century. Their birth resulted from economic (industrialisation), social, cultural and political changes of societies at

1 Łukasz Adamski, Nacjonalista postępowy. Mychajło Hruszewski i jego poglady na Polskę i Polaków (Warszawa: Wydawnictwo Naukowe PWN, 2011), 12-24.

2 Adam Świątek, Gente Rutheni, natonie Poloni: z dziejów Rusinów narodowości polskiej w Galicji (Kraków: Księgarnia Akademicka, 2014), 38-46.

3 Marta Studenna-Skrukwa, Ukraiński Donbas: oblicza tożsamości regionalnej (Poznań: Wydawnictwo Nauka i Innowacje, 2014), 33-42.

4 Józef Chlebowczyk, O prawie do bytu małych i młodych narodów: kwestia narodowa i procesy narodowotwórcze we wschodniej Europie Środkowej w dobie kapitalizmu (od schyłku XVIII do początków XX w.) (Warszawa-Kraków: Państwowe Wydawnictwo Naukowe, 1983), 38-55, 154-157; cf. Benedict Anderson, Wspólnoty wyobrażon: rozważania o źródłach i rozprzestrzenianiu się nacjonalizmu, trans. Stefan Amsterdamski (Kraków: Znak; Warszawa: Fundacja im. Stefana Batorego, 1997), 56; Miroslav Hroch, Małe narody Europy: perspektywa historyczna, trans. Grażyna Pańko (Wrocław: Zakład Narodowy im. Ossolińskich, 2003), 10-11, 91-94, 112-114; cf. Ernest Gellner, Narody i nacjonalizm, trans. Teresa Hołówka (Warszawa: Państwowy Instytut Wydawniczy, 1991), 53-57, 81-95; Krzysztof Pomian, Europa i jej narody, trans. Małgorzata Szpakowska (Gdańsk: słowo/obraz terytoria, 2009), 101, 117-119, 122-124, 142-143, 157-158. 
that time, which lead, among other, to final dissolution of estate system and to the appearance of nationalisms 5 .

The process of national identification was especially complicated and confusing at the turn of the $20^{\text {th }}$ century in Central and Eastern Europe. It is because it did not develop evenly and smoothly. It advanced at different pace in particular national groups and in particular parts of the region. At that time, different groups of seemingly contradictory characteristic features could coexist within what is considered to be one nation. That was, for instance, the case of Gente Rutheni within the Polish or Ukrainian nation. That idea is going to be expanded furthermore in this article. Generally, mentioned above national identification process appeared to be full of turmoil and shifts. Taking all above into consideration, I came to the conclusion, that the theory of modern nations allows to explain better than other the ambiguity of national development in Central and Eastern Europe $e^{6}$.

As sociologist Antonina Kłoskowska claims, nation is the result of a constant "internal process of unification of the culture". That leads her to the conclusion that a particular group or an individual can belong to one nation, although they do not have all features that have been recognized as characteristic for that community. Thus, according to Kłoskowska, a nation does not constitute a fully homogeneous unity ${ }^{7}$. She also states that a person can identify with many national communities (cultures) at the same time ${ }^{8}$. Kłoskowska adds that "The sense of national belonging and the relationship with national culture often, though not always, play an important role in the entire identity of a modern man. It should be remembered, however, that they do not fully define his/her identity"9. In other words, there is more to one's identity than only national identification.

Kłoskowska's conclusions could be helpful in understanding the complicated social, political and economic situation that occurred at the turn of the $20^{\text {th }}$ century in Central and Eastern Europe. There were some groups of population that preserved specific, unique ethnic features. They did not match to those characteristic for and cultivated inside leading modern national groups that have been forming

5 Hroch, Małe narody Europy, 99-100, 112-113; Studenna-Skrukwa, Ukraiński Donbas, 33. A different interpretation of that phenomenon has been presented in: Tomasz Stryjek, Jakiej przeszłości potrzebuje przyszłość?: interpretacje dziejów narodowych w historiografii i debacie publicznej na Ukrainie 1991-2004 (Warszawa: Instytut Studiów Politycznych PAN. Oficyna Wydawnicza Rytm, 2007), 14-16.

6 I have analysed those processes in details in the book: Magdalena Nowak, Dwa światy: zagadnienie identyfikacji narodowej Andrzeja Szeptyckiego w latach 1865-1914 (Gdańsk: Wydawnictwo Uniwersytetu Gdańskiego, 2018), 9-15.

Antonina Kłoskowska, Kultury narodowe u korzeni (Warszawa: Wydawnictwo Naukowe PWN, 1996), 24, 43-44, 138; see more on that in context of the first half of the $20^{\text {th }}$ century in Ukraine: Stryjek, Ukrainska idea narodowa okresu międzywojennego (Toruń: Wydawnictwo Naukowe Uniwersytetu Mikołaja Kopernika, 2013), passim.

8 Kłoskowska, Kultury narodowe u korzeni, 162.

9 Ibidem, 141. 
at that time in the region. Nevertheless, the analysis of lives and choices of their representatives allow to demonstrate how ambiguous the process of national identification was. Historians and sociologists' research results, that have been mentioned above, enable us to better understand the phenomenon of Gente Rutheni, natione Poloni in Galicia at the turn of the $20^{\text {th }}$ century. The characteristic of some figures belonging to that group could be good exemplification of ambiguity of national belonging and national identity in our part of Europe at that period of history.

The aim of this analysis is to show this ambiguity of national identification on the example of Gente Rutheni, natione Poloni. I would compare the biographies of some chosen figures from that group published in Polish and Ukrainian scholarly encyclopaedias and biographical dictionaries. The results should help demonstrate how the $19^{\text {th }}$ and the $20^{\text {th }}$ century national categories, however represented by the same ethnonyms, significantly differ in meaning and socio-political and cultural context from today's. The lack of understanding of that phenomenon could lead members of the public to believe simplified and inadequate opinions on the historical roots of today's nations. In other words, the use of those examples can be instrumental in arousing critical thinking. At the same time I would like to find differences and similarities between presentations of Gente Rutheni, natione Poloni biographies in Polish and Ukrainian scholarly encyclopaedic publications. These could provide some clues about the ways historians of both nationalities explain that phenomenon.

The biographical notes analysed in the text have been published in the encyclopaedic series prepared by Polish Academy of Arts and Sciences and Polish Academy of Science (Polski słownik biograficzny - The Polish Biographical Dictionary ${ }^{10}$ ) as well as the Shevchenko Scientific Society (Енциклопедія Українознавства - Enсуclopedia of Ukraine ${ }^{11}$ ), the Institute of History of Ukraine (Енциклопедія історіi України - the Encyclopedia of History of Ukraine ${ }^{12}$ ).

Gente Rutheni, natione Poloni are described in the scholarly literature as a group living on the territory of Halicz Rus' which was incorporated into the Kingdom of Poland and became later the part of the Polish-Lithuanian Commonwealth. According to Andrzej A. Zięba and Adam Świątek, that group had been forming on the Polish-Ruthenian borderland from the $14^{\text {th }}$ century ${ }^{13}$. Marian

10 Polski słownik biograficzny, eds. Władysław Konopczyński et al., 51 vols. (Kraków: Polska Akademia Umiejętności; Wrocław: Wydawnictwo Zakładu Narodowego im. Ossolińskich, 1935-2017).

11 Encyclopedia of Ukraine, eds. Volodymyr Kubijovyč, Danylo Husar Struk, 5 vols. (Toronto: University of Toronto Press, 1984-1993); I will refer to its Ukrainian version: Енциклопедія Українознавства, сл. ч. 1-11, ed. Володимир Кубійович (Paris: Shevchenco Scientific Society, 1955-1995).

12 Енциклопедія історії України, eds. Валерій А. Смолій et al., 10 vols. (Київ: Національна Академія Наук України, Інститут історії України: Видавництво "Наукова думка" 2003-2013).

13 Andrzej A. Zięba, "Gente Rutheni, natione Poloni: z problematyki kształtowania się ukraińskiej świadomości narodowej w Galicji”, in Prace Komisji Wschodnioeuropejskiej, vol. 2, 
Mudryj dated that process at the turn of the $18^{\text {th }}$ century ${ }^{14}$. The term gente Rutheni, natione Poloni began to be actually used in the $19^{\text {th }}$ century ${ }^{15}$. "In the socio-political discourse in Galicia - claimed M. Mudryj - the term gente Rutheni, natione Poloni appeared in the first half of the $19^{\text {th }}$ century. It referred to political and national self-identification of Polish patriots of the Ruthenian origin who participated in the forming of new Polish intelligentsia"16. According to Mudryj, they wished to return to the Polish-Ruthenian union from the times of the Commonwealth and refresh it in Galicia. At the same time they diagnosed the crisis of that idea. For Polish politicians they became the channel of communication with Ukrainian political society. For Ukrainians they signalled the need for quick establishing and securing Ukrainian national territory. The representatives of that group were recognised as renegades by supporters of separate Ruthenian/Ukrainian national projects ${ }^{17}$. They could be found in Galicia till the beginning of the $20^{\text {th }}$ century, when the birth of modern Ukrainian national identity and the end of estate system resulted in their final disappearance ${ }^{18}$.

Gente Rutheni, natione Poloni are described to have double identity (two-level): ideological - natio and regional-ethnic - gens. The first was associated with belonging to the "political nation" of the Commonwealth and by that to the Polish culture. The second was connected with Ruthenian families cultivating the memory about their originally Ruthenian religion (Orthodoxy, Uniate), ethnicity, language (Ruthenian) and tradition. Those identities did not collide because they belonged to different spheres: political and ethnic ${ }^{19}$. At first, this phenomenon occurred among various groups of Ruthenian gentry. Then it spread over the clergy, the towns people and finally the intelligentsia ${ }^{20}$.

At the turn of the $18^{\text {th }}$ century and in the first half of the $19^{\text {th }}$ century gente Rutheni, natione Poloni showed signs of steady process of Polonisation. They often

eds. Ryszard Łużny, Andrzej A. Zięba, (Kraków: Polska Akademia Umiejętności, 1995), 61-66; Świątek, Gente Rutheni, natione Poloni, 34-37.

14 Marian Mudryj, "Powstanie styczniowe a środowisko gente Rutheni, natonie Poloni w Galicji", in Powstanie styczniowe: odniesienia, interpretacje, pamięć, ed. Tomasz Kargol (Kraków: Towarzystwo Wydawnicze "Historia Iagellonica" 2013), 67.

15 Swiątek, Gente Rutheni, natonie Poloni, 34.

16 M. Mudryj, "Formacja gente Rutheni, natonie Poloni w XIX-wiecznej Galicji a pojęcie ojczyzny", in Formuly patriotyzmu w Europie Wschodniej i Środkowej od nowożytności do współczesności, eds. Nowak, Zięba (Kraków: Polska Akademia Umiejętności, 2009), 285.

17 Мар'ян Мудрий, “Ідеа польсько-української унії та русини польської нації в етнополітичному дискурсі Галичини 1859-1869 років”, Вісник Львівського Університету, серія історична 39-40 (2005): 83-85, 146-148.

18 Zięba, "Gente Rutheni, natione Poloni”, 61-66; Świątek, Gente Rutheni, natonie Poloni, 34-37.

19 Mudryj described the process of forming gente Rutheni, natonie Poloni group as the reaction of the local Ruthenian/Ukrainian society to the birth of Polish modern national identity. Mudryj, "Powstanie styczniowe a środowisko”, 67; idem, „Formacja gente Rutheni, natonie Poloni”, 285.

20 Zięba, "Gente Rutheni, natione Poloni”, 61-66; Świątek, Gente Rutheni, natione Poloni, 11; Mudryj, "Formacja gente Rutheni, natonie Poloni", 288-289. 
used Polish language in their public - and Rutnenian or Polish in private life. Some of them changed their rite from the Greek-Catholic to the Roman Catholic. Moreover, many members of that group were active in Polish insurgent movement ${ }^{21}$. However, in the second half of the $19^{\text {th }}$ century that trend reversed.

The Ruthenian/Ukrainian culture was preserved in pheasant group. Moreover, its elements survived in the historic memory of higher social groups. Both of those aspects were used by Ruthenian/Ukrainian national emancipation movement ${ }^{22}$. Consequently, some of gente Rutheni return to their families' roots, recalling their Ruthenian past. There were a couple of factors that influenced that. On one hand, belonging to gente Rutheni, natione Poloni was traditionally associated with having lower social status than that which was ascribed to the Polish gentry. On the other hand, the rapid growth of Polish nationalism and consequent increasing level of social, political and religious conflict deterred gente Rutheni gentry from Polish national democrats and their supporters ${ }^{23}$. Finally, the remnants of former "political nation" ceased to exist and gente Rutheni, natione Poloni had assumed either Ukrainian or Polish modern identity ${ }^{24}$.

Among those, who were described as gente Rutheni, natione Poloni, there were some clergymen. One of the most important and controversial such figures was metropolitan Andrei (Roman Aleksander) Sheptyts'kyi ${ }^{25}$. Zięba placed Andrei Sheptyts'kyi among those members of previously Polonised families who had „escaped” Polish nation in order to support one of competing national projects of the neighbours, in his case Ukrainian. Sheptyts'kyi was an aristocrat, a grandson of Polish writer Aleksander Fredro. There was almost no trace of Ruthenian/ Ukrainian influence in his mother's - Zofia neé Fredro - family. However, the memory of high ranking hierarchs in the Uniate Church in the Commonwealth was preserved in his father's, Jan Kanty, family. Culturally presenting itself as Polish, Sheptyts'kyi's family cultivated a vivid memory of its Ruthenian roots. After completing doctors' degree at the Jagiellonian University, in 1888 Roman Sheptyts'kyi joined the Basilian order. In 1892 he took his monastic vows. By doing that he changed his rite from Catholic into Greek-Catholic. In the same year he was ordained a priest. After a short but successful career in the monastery in 1900 he was nominated a bishop oh Stanislaviv. A year later he became an archbishop

21 Świątek, Gente Rutheni, natione Poloni, 10-11.

22 Mudryj claims that double identification of gente Rutheni, natione Poloni was a reaction to the birth of modern Ruthenian identity In fact, according to this author, those who declared themselves openly as gente Rutheni, natione Poloni had already chosen Polish identity. Mudryj, "Formacja gente Rutheni, natonie Poloni", 288-289.

23 Mudryj, "Formacja gente Rutheni, natonie Poloni", 290.

24 Zięba, "Gente Rutheni, natione Poloni”, 66-77; Świątek, Gente Rutheni, natonie Poloni, 13; Mudryj, "Formacja gente Rutheni, natonie Poloni", 296.

${ }_{25}$ Zięba, "Zbiegostwo: dylematy ideowe XIX-wiecznych patriotów na ziemiach dawnej Rzeczypospolitej”, in Formuly patriotyzmu w Europie Wschodniej i Środkowej, 147. 
of Lviv, metropolitan of Halych and a bishop of Kamenets'-Podil's'kyi. As such he acted on behalf of his Ukrainian, Greek-Catholic faithful, consequently supporting their cultural, social and political development. He continued to do so during the Second World War, supporting proclamation of independent Ukrainian state in 1941 . He died in 1944 after Lviv was captured by the Soviets.

Writing Andrei Sheptyts'kyi's biographical note for Polski słownik biograficzy - Polish Biographical Dictionary, I tried to present both his connection with Polish culture and Catholic religion in his young years and his contribution to the Ukrainian social, political and cultural life as metropolitan. I underlined the fact that in the records at the Jagiellonian University he was registered first as Polish but later, in 1885 he, probably with his own hand, changed his declaration from 'Polish' into 'Ruthenian'. Consequently, he showed great involvement in the Ukrainian matters as metropolitan, supporting their plans for national independence after the First and during the Second World War. To fully present Sheptyts'kyi's figure it was important to highlight his role in Polish-Ukrainian relations, his efforts to support some cooperation between both nations ${ }^{26}$.

Енциклопедія Українознавства - Encyclopedia of Ukraine and Енциклопедія icmoріï України - the Encyclopedia of History of Ukraine both contain biographical notes on Sheptyts'kyi ${ }^{27}$. Irrespectively of the fact that those notes were published in different years (1984 and 2013) there are similar in terms of contents. Their authors underlined the fact that Sheptyts'kyi felt and acted as Ukrainian. $\mathrm{He}$ is presented as a monolith, which always supported Ukrainian actions. They underline that he came from old Ruthenian gentry family. However Encyclopedia of Ukraine states that the Sheptyts'kyi falmily was Polonised and that metropolitan returned to his family tradition. Comparing to the note in Polski słownik biograficzny - The Polish Biographical Dictionary both Ukrainian texts contain some simplifications. Their authors have omitted the problem of Sheptyts'kyi's change of religious right. Moreover, his efforts to maintain peace between Polish and Ukrainian societies have been hardly mentioned there. Generally, Sheptyts'kyi's attitude towards German occupation during the Second World War has been described as unambiguously negative. On one hand, Sheptyts'kyi's pastoral letter greeting German army entering Galicia has been omitted in both Ukrainian texts. On the other hand, his support for Yaroslav Stetsko's declaration of a Ukrainian National Government, 30 June 1941, has been strongly underlined. Енциклопедія

26 Nowak, "Szeptycki Roman, w zakonie Andrzej", in Polski słownik biograficzny 48/2 (197), eds. Konopczyński et al. (Kraków: Polska Akademia Umiejętności, 2012), 216-224; see Nowak, Dwa światy, 222-230, passim.

27 Ю.А. Черченко, “Шептицький Андрей”, in: Енциклопедія історії України 10, eds. Валерій A. Смолій et al. (Київ: Національна Академія Наук України, Інститут історії України: Видавництво “Наукова думка” 2013), 631-633; В. Ленцик, “Шептицький Андрей”, in Енциклопедія Українознавства, сл. ч. 10, ed. Володимир Кубійович (Paris: Shevchenco Scientific Society, 1984), 3841-3844. 
Українознавства - Encyclopedia of Ukraine has also stated that Sheptyts'kyi presented generally negative attitude towards all three "occupants": Polish, German and Soviet. In both texts Sheptyts'ky is rightly presented as being strongly against terror, but his negative attitude towards Ukrainian terror (e.g. the killing of Andrei Potocki, 1908) is not clearly stated. Moreover, both texts contain some mistakes in facts and dates, which is understandable in context of complexity of Sheptyts'kyi's personality and multitude of publications concerning his figure. Generally speaking, all three texts contain the most important facts from Sheptyts'kyi's life. However, Polish biographical note seems to present more problems concerning interpretation of his figure than both Ukrainian ones. The authors of all three texts highlight such facts that are likely to be interesting for respectively Polish or Ukrainian reader.

The next clergyman that could be analysed in the context of Gente Rutheni, natione Poloni is Julian Sas-Kuilovs'kyi $(1826-1900)^{28}$. He was a auxiliary (1890-1891) and then diocesan bishop of Stanislaviv (1891-1898) and an archbishop and metropolitan of Lviv (1899-1900). His family had belonged to the gentry. He was the Greek Catholic priest's son. As a young man he took part in the events of the Spring of Nations, he fought in the Hungarian uprising. After his defeat, he joined the Turkish army. Then, he found himself in Paris under the care of the resurrectionists. He joined the Ruthenian college for the eastern mission and graduated from the seminary. In 1854 he was ordained in the Latin rite with the obligation to celebrate the liturgy in the Greek-Byzantine rite. Three years later he was amnestied and he came to Galicia. For 25 years he had served as the Uniate parish priest in the village of Ruskie Sioło near Przemyśl. In 1878 he was granted an audience with Leon XIII and as a result, quickly promoted. In 1887 he took a position of archpriest (archiprezbiter) and chairman of the Stanislaviv chapter and then he moved to Stanislaviv. In 1890 he was appointed auxiliary bishop of the Przemyśl eparchy. After the death of her bishop, Kuilovs'kyi took over the administration of the diocese as vicar. In the years 1891-1898 he was the bishop of Stanislaviv diocese. In the years 1899-1900 he was archbishop and metropolitan of Lviv. As a parish priest he was favoured by local noble families, e.g. Sapiehas from Krasiczyn. As a bishop and metropolitan, he was considered to have strong ties with Western European and Polish culture. He was described as a Polonophile. According to W. Osadczy, it was due to the Polish support that Kuilovs'kyi obtained his position of metropolitan. His promotion was regarded with distrust by the other Greek Catholic priests ${ }^{29}$.

28 Czesław Lechicki, "Kuiłowski Julian”, in Polski słownik biograficzny 16, eds. Konopczyński et al. (Kraków: Polska Akademia Umiejętności, 1971), 111-112; “Куїловський-Сас Юліян”, in Енцииклопедія Українознавства, сл. ч. 4 (Paris: Shevchenco Scientific Society, 1962), 1226.

29 See Czesław Partacz, Od Badeniego do Potockiego: stosunki polsko-ukraińskie w Galicji w latach 1888-1908 (Toruń: Wydawnictwo Adam Marszałek, 1997), 75-76; Włodzimierz Osadczy, Święta Ruś: rozwój i oddziaływanie idei prawosławia w Galicji (Lublin: Wydawnictwo Uniwersytetu Marii 
Yulian Sas-Kuilovs'kyi's biographical note for Polski słownik biograficzny - Polish Biographical Dictionary written by Czesław Lechicki highlighted his links with the Polish and Eastern-European culture. Kuilovs'kyi was described as "different from the rest of the Greek-Catholic hierarchy in the $19^{\text {th }}$ century". It was underlined that while in exile Kuilovs'kyi had contacts with Adam Jerzy Czartoryski and Hotel Lambert, Adam Mickiewicz and ex-resurrectionist Hipolit Terlecki. Moreover Lechicki described an incident that took place at Vienna railway station, where Kuilovs'kyi and metropolitan Sylvester Sembratovych were insulted by a group of Ukrainian radical youth. As metropolitan Kuilovs'kyi had difficulty to be accepted by Ukrainian community. One of the reasons was, as presented in his note, the fact that he spoke Polish during the celebration of 300-anniversary of Union of Brest (1896) ${ }^{30}$.

All those, mentioned above, elements were not included in Kuilovs'kyi's Ukrainian biographical notes. The note on him presented in Енциклопедія Українознавства - Encyclopedia of Ukraine is very short and contains only very basic information on his most important functions in the Church ${ }^{31}$. However, a text on him included in the Енциклопедія історіі України - the Encyclopedia of History of Ukraine is more elaborate. It is authored by Ukrainian historian Olena Arkusza, who specialises $19^{\text {th }}$ century Galicia. She highlighted different elements, than those mentioned in Lechcki's note, that had connected Kuilovs'kyi with the Polish culture. During the Spring of Nations Kuilovs'kyi fought in Polish and later Hungarian uprising (as a member of a Polish Legion). Arkusza underlined the fact that he was chosen metropolitan due to Polish and Vienna support. Authorities in Austria and in Galicia wanted to impose limitations on Greek-Catholic clergy social and political activity. Arkusza also underlined that Kuilovs'kyi's efforts to incorporate such policy were not met with understanding from the Ukrainian side. As a result, he restricted his activity to Church and charity matters. Arkusza also focused on his conservative views on ecclesiastical problems. She highlighted that he was against the introduction of phonetic script in the Ukrainian language. In that he presented the same position as Moscophiles. Finally, the author of the Ukrainian note stated that Kuilovs'kyi supported the Greek-Catholic Church expansion on the territory of the Russian Empire ${ }^{32}$.

The two biographical notes, in Polski słownik biograficzy - Polish Biographical Dictionary and Енииклопедія історії України - Encyclopedia of History of Ukraine,

Curie-Skłodowskiej: Europejskie Kolegium Polskich i Ukraińskich Uniwersytetów. Instytut Europy Środkowo-Wschodniej, 2007), 448.

30 Lechicki, "Kuiłowski Julian”, 111-112.

31 “Куїловський-Сас Юліян”, in Енциклопедія Українознавства, сл. ч. 4 (Paris: Shevchenco Scientific Society, 1962): 1226.

32 Олена Г. Аркуша, “Куїловський-Сас Юліян”, in Енциклопедія історії України 5, eds. Валерій А. Смолій et al. (Київ: Національна Академія Наук України, Інститут історії України: Видавництво “Наукова думка” 2008), 454-455. 
were published in different time $(1971,2008)^{33}$. Their authors both highlighted the fact that Kuilovs'kyi was connected with the Polish culture. No strangely, Polish note included more information on Kuilovs'kyi's contacts with representatives of Polish elite. Whereas in the Ukrainian note bad relations with Ukrainian side were presented. However, that was Lechicki who recalled the incident at the railway station. Arkusza did not present that fact. She also omitted information that he was consecrated in the Latin rite. Both biographical notes seem to be complementary and focus on Kuilovs'kyi's most important features. However they use different facts to illustrate his position in-between Polish and Ukrainian side.

The last clargyman whose biographical notes I would like to analyse is Klyment Sarnyts'kyi (1832-1909). He was baptised in the Latin rite. After he had been relegated from the Roman Catholic seminary in Lviv, he joined the Basilian order. He was a theologian, professor at the University of Lviv. He held various academic positions, among others - the dean of the Faculty of Theology and the rector of the university. He was known as an excellent biblical scholar. Since 1871 he had been a co-editor (with Sylvester Sembratovych and Yulian Pelesh) of a diocesan journal “Rusky Sion” („Рускій Сіонъ). In 1878 he took a position of Basilian provincial superior (protoihumen) in Galicia. He was an initiator and a supporter of the Jesuit involvement in the Dobromil reform which began in 1882. In the years that followed it he was the provincial superior of the non-reformed Basilians. In 1901 he became their archimandrite. Because of his role in initiating the reform he was attacked by Ukrainian monks, clergy and intelligentsia. His death marked the end of existence of unreformed Basilians $s^{34}$.

Sarnyts'kyi has two biographical notes, in Polski słownik biograficzny - Polish Biographical Dictionary and in Енииклопедія Українознавства - Encyclopedia of Ukraine. There is no entry on him in Енциклопедія історії України - Enсyclopedia of History of Ukraine. In his case there is no balance between a comprehensive, Polish note authored by Zięba and rather short and limited anonymous note in Енциклопедія Українознавства. The latter gives only a general outline of Sarnyts'kyi's life and his scholarly activity. It underlines the fact that Sarnyts'kyi introduced Dobromil reform according to Pope's instruction. Such a picture contrast sharply with elaborate description written by Zięba. The latter gave a detailed presentation of Sarnyts'kyi's education and academic work, recalling his numerous scholarly publications. The circumstances of the Dobromil reform introduction were presented in detail. Zięba underlined the core role of Sarnyts'kyi's opinion and

33 Kuilovsky's note in Енциклопедія Українознавства - Encyclopedia of Ukraine does not contain enough information for comparison.

34 Zięba, "Sarnicki Kasjan Klemens", in Polski słownik biograficzny 35/2 (145), eds. Konopczyński et al. (Kraków: Polska Akademia Umiejętności, 1994): 214-217; Hieronim Eugeniusz Wyczawski, "Sarnicki Klemens", in Słownik polskich teologów katolickich 4, ed. Wyczawski (Warszawa: Akademia Teologii Katolickiej, 1983): 22-23; “Сарницький Климент Кароль”, іn Енциклопедія Українознавства, сл. ч. 7, (Paris: Shevchenco Scientific Society, 1973), 2711. 
support in initiating the reform. He also showed the Basilian opposition against it and Sarnyts'kyi's role in its overcoming. Zięba quoted numerous examples of opinion on Sarnyts'kyi, citing from the press and recalling reaction of various Ukrainian and Polish communities. He underlines that Sarnyts'kyi had support of Vatican and Vienna authorities. The author of the note gave various examples of Sarnyts'kyi's connection with the Polish community (e.g. A. Mickiewicz funeral in Wawel or celebrations to Sarnyts'kyi's honour at the Lviv University). Finally, Zięba showed that there were hardly no Greek-Catholic clergy at the Sarnyts'kyi's funeral and there was a complete absence of Basilian monks there.

Only partly could the disproportion between Polish and Ukrainian biographical note on Sanrnyts'kyi result from the difference in time when they were published $(1994,1973)$. The most important is the fact that Sarnyts'kyi's deeds are better understood and more accepted from the Polish perspective. Consequently, he is seen as gente Ruthenus, natione Polonus and his actions and connections with the Polish society are appreciated. However from the Ukrainian perspective he is hardly noticed, as somebody who did not have understanding of Ukrainian society. His role is restricted to simply executing the Pope's order. In this way the author of Ukrainian note avoided presenting the ambiguity of Polish-Ukrainian relations in Galicia and gente Rutheni, natione Poloni identity.

Analysis of Polish and Ukrainian Biographical notes on three clergy who lived and acted in the second half of the $19^{\text {th }}$ century enables to draw some conclusions. Firstly, those gente Rutheni, natione Poloni who were perceived by contemporary Ukrainians as acting against the Ruthenian/Ukrainian emancipation (Kuilovs'kyi, Sarnyts'kyi) are less recognised in the Ukrainian scholarly encyclopaedias. Their connections with Polish society are not comprehensively presented there. On the other hand they are elaborately described in Polski słownik biograficzny. The case of Sheptyts'kyi' s biographical note is different. His figure is presented in detail in Polish and Ukrainian encyclopaedias. During his life he became accepted and appreciated by Ukrainian community and rejected by the Polish one. As a result, Polish and Ukrainian notes on him highlight different facts. The Polish note shows complexity of his position and reactions, sometimes even underlining his staying in-between two nations. Ukrainian notes underline his pro-Ukrainian activity, avoiding talking on ambiguities of his behaviour and reactions. Finally, it is important to underline the unprecedented role of the authors of biograms (e.g. Arkusza, Zięba), whose professionalism influence the way particular figures are presented.

Comparing of Polish and Ukrainian biographic notes show how ambiguous were national identities in our part of Europe at the turn of the $20^{\text {th }}$ century. It also helps to understand the differences in today's perceiving particular figures from that time. It is especially relevant for gente Rutheni, natione Poloni group. 


\section{Magdalena Nowak \\ Gente Rutheni, natione Poloni in Polish and Ukrainian scholarly encyclopaedias and biographical dictionaries}

\section{Summary}

Polish and Ukrainian biographical notes on three clergy, that have been analysed in the article, allow us to draw some conclusions. Firstly, some gente Rutheni, natione Poloni were perceived by contemporary Ukrainians as acting against the Ruthenian/Ukrainian emancipation (Kuilovs'kyi, Sarnyts'kyi). Their biographical notes are usually less elaborate in the Ukrainian scholarly encyclopaedias. What is more, their connections with Polish society are not comprehensively presented there. They are elaborately described in Polski stownik biograficzny though. The case of Sheptyts'kyi' s biographical note is different. His figure is presented in detail in Polish and Ukrainian encyclopaedias. Polish and Ukrainian notes on him highlight different facts. The Polish note shows complexity of his position and reactions, sometimes even underlining his staying in-between two nations. Ukrainian notes underline his pro-Ukrainian activity, avoiding talking on ambiguities of his behaviour and reactions.

Comparison of Polish and Ukrainian biographic notes show ambiguity of national identities at the turn of the $20^{\text {th }}$ century. It also helps to understand the differences in today's perception of particular figures. It is especially relevant for gente Rutheni, natione Poloni group. 